\title{
Impact of Vocational and Entrepreneurship Education on the Economic Growth of Ogun State, Nigeria
}

\author{
Oyenuga Anthony Oyetunde ${ }^{1, *}$, Odunaike Kaolat Oluwafemi ${ }^{1}$, Amoda Morili Bisola ${ }^{1}$ \\ ${ }^{1}$ Tai Solarin University of Education, Nigeria [*Corresponding author: tajeam@yahoo.com]
}

\begin{abstract}
This paper reports the findings of a study that delved into the impact of vocational and entrepreneurship education (VEE) on the economic growth of Ogun State, Nigeria. Specifically, the study investigated the extent to which VEE can enhance the economic growth of the state and the factors inhibiting its development. Data was collected from 250 VEE educators in the state. These responded to a questionnaire. The questionnaire was validated by six experts in VEE and, using Cronbach's alpha, the reliability of the instrument was found to be .82. The data collected was analysed using means and standard deviation while the t-test statistics was used to test the hypotheses at .05 level of significance. It was found that VEE is a factor for the economic growth of the state. Therefore, it is recommended that VEE is given the priority that it deserves notably in the area of funding.
\end{abstract}

Keywords: Curriculum Reform; BTVET; Development.

\section{$1 \quad$ Introduction}

Vocational education is an instrument necessary for uplifting and promoting a sustainable development. It involves the necessary skill that would be needed for economic growth. Invariably, in Nigeria today, vocational education is yet to be accorded with the required attention and this is due to poor policy implementation. According to Otuaga, (2012), advancement and sustainable development is a very vital issue in a global world. He further stated that vocational education is focused on acquisition of individual skills and capability for occupation. Vocational education has been an integral part of national development strategies in many societies because of the impact on human resource development, productivity and economic growth (Oguejiofor 
and Ezeabasili, 2014). The duo further stated that vocational education entails the enrichment of the capabilities that influence the effective psychomotor or cognitive domains of individual in readiness for entry into the world of work in order to satisfy their intrinsic and extrinsic values, work, and aspirations such that local and national needs would be met. Indeed, vocational education in Nigeria must emphasize entrepreneurship awareness for it to be relevant in achieving economic growth of any state/nation. However, vocational education combines human and material resources for the promotion of sustainable occupational development and this can also be linked to entrepreneurship education.

Entrepreneurship education like vocational education as well requires the skills that will enable individuals that would not want to rely on white-collar job for a living. According to Emeraton (2008), entrepreneurship education deals with those attitudes and skills that are necessary for the individual to respond to his environment in the process of conserving, starting and managing a business enterprise.

Entrepreneurship education should involve both literate and illiterate citizens. The reason being that not every individual has the opportunity for formal education and everyone wanted to be successful in any occupation he/she finds him/herself. This assertion is in line with Oduwaiye (2005) that entrepreneurship education prepares individual to properly acquire saleable skills which could be used to manage his/her own business or that of another person. Therefore, entrepreneurship education is an education that would equips individual formally or informally with knowledge, skills, idea, motivation as well as management ability in any occupation necessary for self-sustenance.

VEE may not be separated since the two involves combination of human and material resources for productivity. Therefore, VEE requires the acquisition of ability, knowledge, skills and competencies that would make individual to be productive and useful for the challenges of unemployment in the world of work. With the above, one can say that VEE may play a very important role in the economic growth of any state in a country in which Ogun State, Nigeria is one. However VEE if not given the attention it requires, it may one way or the other inhibit the economic growth of Ogun State. To this extent, for any state/nation to be developed, her citizens must be economically productive in order to contribute to her economic growth. This may be achieved through VEE which is the focus of this study.

\section{Statement of the Problem}

VEE involves the necessary skill and competence that would be needed for economic growth. It involves step by step learning of skills that will bring out the knowledge and competencies in an individual. Just because of the 
challenges facing VEE in the Ogun State, little could be done to energize the competence in individual since the motivation in this regard is nothing to write about. Invariably, in Nigeria today in which Ogun State is one of the states in the country, VEE is yet to be accorded with the required attention and this is may be due to poor policy implementation. Inadequate practical work in vocational and entrepreneurship education courses in most tertiary institutions in Ogun State due to in-availability of adequate manpower, equipment, machines and necessary tools contributed to the problems facing VEE in the state. Therefore, for VEE to really take its place in the economic growth of Ogun State the problems facing it has to be addressed.

\section{Purpose of the Study}

The purpose of the study is to examine the impact of VEE on the economic growth in Ogun State, Nigeria. Specifically, the study seeks to determine:

Whether VEE can enhance economic growth in Ogun State, Nigeria.

The factors that may inhibit VEE from enhancing economic growth in Ogun State, Nigeria.

\section{Research Questions}

1. To what extent can VEE enhance economic growth in Ogun State, Nigeria?

2. What are the factors that may inhibit VEE from enhancing economic growth in Ogun State, Nigeria?

\section{Research Hypotheses}

1. There is no significant difference in the mean responses of male and female VEE educators on the extent to which VEE could enhance economic growth in Ogun State, Nigeria.

2. There is no significant difference in the mean responses of male and female VEE educators on the factors that may inhibit VEE in enhancing economic growth in Ogun State, Nigeria.

\section{Methodology}

The research design adopted for the study is a survey design. The design was adopted because the variables of the study were not subjected to any manipulation as they have already occurred in the field before the research started (Alade, 2011).

The population of the study consists of 250 vocational and entrepreneurship educators in tertiary institutions in Ogun State, Nigeria. The tertiary institutions 
are: Tai Solarin University of Education, Ijagun; Olabisi Onabanjo University, Ago-Iwoye; Moshood Abiola Polytechnic, Abeokuta; Federal Polytechnic, Ilaro; Tai Solarin College of Education, Omu-Ijebu and Abraham Adesanya Polytechnic, Ijebu-Igbo. The vocational and entrepreneurship educators are 250 in number. There was no sample since the whole population was used for the study.

A structured questionnaire was used. This comprises of eleven-item questionnaire that covers research question 1 and nine-item questionnaire that covers research question 2. A four-point rating scale which is modification of Likert-Scale was used for the study. The instrument ratings are Strongly Agree (SA) - 4, Agree (A) - 3, Disagree (D) - 2 and Strongly Disagree (SD) - 1 .

The instrument was subjected to face validation by six experts in VEE. Their observations, comments and suggestions were taken into consideration for the final draft of the instruments.

The researchers administered the questionnaire to the respondents with the help of six research assistants employed from each of the institution used for the study. The filled questionnaire was collected immediately. The entire 250 questionnaire were returned.

For the establishment of the reliability of the instrument, the instrument was administered on 30 vocational and entrepreneurship educators from five institutions in Lagos State, Nigeria. The institutions are: University of Lagos, Lagos State University; Lagos State Polytechnic, Federal College of Education (Technical), Akoka and Adeniran Ogunsanya College of Education, Ijanikin. The institutions are outside the study area. The reliability was established using Cronbach alpha and it was found to be 0.79 . This is an indication that the instruments are reliable.

The research questions were answered using mean and standard deviation while t-test statistics was used to analyse the hypotheses at 0.05 significant level.

A mean of 2.50 and above was taken as an index of agreement while a mean below 2.50 was taken as index of disagreement. Also if the t-calculated is less than the t-table, the null hypothesis is accepted. On the other hand if the tcalculated is greater than the t-table, the null hypothesis is rejected.

\section{Results}

The findings on the impact of VEE on economic growth in Ogun State, Nigeria are summarized in Table 1. 
Table 1: Scores on the extent to which VEE can enhance economic growth

\begin{tabular}{|c|c|c|c|c|}
\hline \multirow[t]{2}{*}{ Attribute } & \multicolumn{2}{|l|}{ Male } & \multicolumn{2}{|c|}{ Female } \\
\hline & Mean & SD & Mean & SD \\
\hline VEE would be an instrument for promoting a perfect sustainable economic growth in Ogun State. & 3.28 & 0.94 & 2.89 & 0.97 \\
\hline Any kind effort for economic growth or initiatives requires human capital amongst others. & 3.68 & 0.57 & 3.49 & 0.81 \\
\hline Development of human capital requires appropriate skills, attitudes and knowledge. & 3.79 & 0.41 & 3.57 & 0.73 \\
\hline Artisans, craftsmen, technicians and technologist require knowledge of VEE to fit in production for growth. & 3.76 & 0.43 & 3.44 & 0.86 \\
\hline Indigenous technology should be encouraged for economic growth. & 3.78 & 0.42 & 3.55 & 0.49 \\
\hline There should be adequate manpower to handle engineering works, agriculture and computer services. & 3.63 & 0.49 & 3.53 & 0.50 \\
\hline $\begin{array}{l}\text { Youth should be equipped with the occupational skills and competencies required for effective participation in } \\
\text { economic growth. }\end{array}$ & 3.69 & 0.46 & 3.50 & 0.50 \\
\hline VEE should be intensified to reduce unemployment and enhance economic growth. & 3.36 & 0.83 & 3.32 & 0.82 \\
\hline $\begin{array}{l}\text { Graduates of various institutions in Ogun State should be given the right education that can give them the } \\
\text { opportunity to be entrepreneurs and contribute to the economic growth of the state. }\end{array}$ & 3.82 & 0.35 & 3.61 & 0.49 \\
\hline VEE will give an individual the ability to exploit market opportunities. & 3.31 & 0.87 & 3.20 & 0.94 \\
\hline VEE should be encouraged in order to safeguard economic conditions and develop physical infrastructure. & 3.12 & 0.91 & 3.03 & 0.98 \\
\hline Weighted Average & 3.57 & 0.61 & 3.38 & 0.74 \\
\hline
\end{tabular}


Table 1 above indicates that both male and female vocational and entrepreneurship educators are in agreement with items 1-11 in the table ranges from a mean of 2.89 to 3.82 and a standard deviation ranges as well from 0.35 to 0.98 respectively. The responses of the respondents are indication that VEE can enhance or boost the economic growth of Ogun State, Nigeria.

Table 2 shows the findings on the factors that may inhibit VEE in enhancing economic growth in Ogun State, Nigeria

Table 2: Mean scores on inhibiting VEE in enhancing economic growth in Ogun State

\begin{tabular}{|c|c|c|c|c|}
\hline \multirow[t]{2}{*}{ Attributes } & \multicolumn{2}{|l|}{ Male } & \multicolumn{2}{|c|}{ Female } \\
\hline & Mean & SD & Mean & SD \\
\hline $\begin{array}{l}\text { Inability to develop necessary skills, especially critical } \\
\text { thinking, communication and teamwork. }\end{array}$ & 3.21 & 0.88 & 3.12 & 0.98 \\
\hline Lack of an access to resources such as workshops. & 3.12 & 0.94 & 3.04 & 0.99 \\
\hline $\begin{array}{l}\text { Inadequate skilled manpower to exploit business } \\
\text { opportunities available. }\end{array}$ & 3.49 & 0.50 & 3.47 & 0.50 \\
\hline $\begin{array}{l}\text { Scarcity of VEE educators poses a challenge to } \\
\text { economic growth. }\end{array}$ & 2.96 & 1.04 & 2.93 & 1.04 \\
\hline $\begin{array}{l}\text { Lack of adequate modern machines and equipment } \\
\text { and tools. }\end{array}$ & 2.96 & 1.04 & 2.99 & 0.99 \\
\hline Inability to develop problem solving skills & 3.16 & 0.83 & 2.98 & 0.93 \\
\hline Lack of practical skills development. & 3.15 & 0.99 & 3.06 & 0.99 \\
\hline Lack of adequate loan facility. & 2.89 & 1.14 & 2.92 & 1.07 \\
\hline Low commitment of government on VEE & 2.78 & 0.99 & 2.92 & 0.99 \\
\hline Weighted Average & 3.08 & 0.93 & 3.38 & 0.77 \\
\hline
\end{tabular}

The result on revealed that all the respondents from items 12 to 20 (both male and female vocational and entrepreneurship educators) agreed on all the items in table with a mean ranging from 2.78 to 3.49 and standard deviation ranging from 0.50 to 1.14 respectively.

Hypothesis one stated that there is no significant difference in the mean responses of male and female vocational and entrepreneurship educators on the extent to VEE could enhance economic growth in Ogun State, Nigeria. The results of testing the hypothesis are shown in Table 3.

Table 3: Significance of difference in mean scores on impact of VEE on economic growth in Ogun State

\begin{tabular}{llllllll}
\hline Variables & $\mathbf{N}$ & Mean & SD & $\mathbf{t}_{\text {cal }}$ & $\mathbf{t}_{\text {tab }}$ & Df & Sf \\
\hline Male & 121 & 3.57 & 0.61 & 1.71 & 1.97 & 248 & 0.05 \\
Female & 129 & 3.38 & 0.74 & & & & \\
\hline
\end{tabular}


Table 3 indicated that the t-calculated value is 1.71 while that of table-value is 1.97 at 0.05 level of significance. This revealed that the null hypothesis one is accepted. This is an indication that the mean responses of male and female vocational and entrepreneurship educators on the extent to which VEE could enhance economic growth in Ogun State was not significant.

Hypothesis 2 stated that there is no significant difference in the mean responses of male and female vocational and entrepreneurship educators on the factors that may inhibit VEE in enhancing economic growth in Ogun State, Nigeria. The results of testing the hypothesis are shown in Table 4.

Table 4: Significance of difference in mean scores on factors inhibiting VEE from contributing to economic growth in Ogun State

\begin{tabular}{llllllll}
\hline Variables & $\mathbf{N}$ & Mean & SD & $\mathbf{t}_{\text {cal }}$ & $\mathbf{t}_{\text {tab }}$ & $\mathbf{d f}$ & $\mathbf{S f}$ \\
\hline Male & 121 & 3.08 & 0.93 & 0.20 & 1.97 & 248 & 0.05 \\
Female & 129 & 3.05 & 0.94 & & & & \\
\hline
\end{tabular}

From Table 4, the t-calculated value is 0.20 and that of table-value is 1.97 at significance level of 0.05 . This is an indication that the null hypothesis two is accepted. Hence, there is no significant difference in the mean responses of male and female vocational and entrepreneurship educators on the factors that may inhibit VEE in enhancing economic growth in Ogun State.

\section{Discussion, Conclusion and Recommendations}

The study tested two hypotheses based on the two research questions formulated. Table 1 shows that all the vocational and entrepreneurship educators agreed with all the items in the table that VEE can really enhance economic growth in Ogun State, Nigeria. Based on the responses of the educators, hypothesis 1 when analysed indicated that there was no significant difference in the mean responses of male and female vocational and entrepreneurship educators on the extent to which VEE could enhance economic growth in Ogun State. Therefore, the hypothesis was accepted.

This result was in agreement with Mustapha and Greeman (2002) in their study on the role of Vocational Education in Economic Development in Malaysia: Educators and Employers' Perspective. The educators and employers believed that vocational education and training contributed to the economic development of Malaysia. The result was also in agreement with Wennekers, Van-Wennekers, Thurik, and Reynolds (2005) in their study on Nascent Entrepreneurship and the Level of Economic Development, Small Business Economics that promotion of entrepreneurial education is especially recommended in low-income nations, besides improvements of confidence in 
property rights, guarantee access to capital, safeguard safe economic conditions, develop physical infrastructure.

The result as well corroborates Kazmi (2007) in which his study pointed out that vocational training and skill development are the tools to improve productivity of the labour force of any country. Both the vocational training and skill development are the most impact factors of human capital development of a country. The result also supported Uduma (2004) that with entrepreneurship, individual will combine human and material resources in order to produce goods and services desired by man. From the result of Uduma (2004), human and material resources play a vital role in economic growth of any state or nation.

Table 2 as well indicated that all the vocational and entrepreneurship educators agreed on the factors that may inhibit VEE in Ogun State, Nigeria. With this agreement, hypothesis 2 after the analysis showed that there was no significant difference in the mean responses of male and female vocational and entrepreneurship educators on the factors that may inhibit VEE in enhancing economic growth in Ogun State.

This result corroborates Kazmi (2007) that both the vocational training and skill development are the most impact factors of human capital development of the country. This shows that without vocational training and skill and human capital development for the economic growth of a state or nation would be nothing to write about. The result also supported Nilsson (2010) study that vocational education and training are the most important factors for economic growth as well as social inclusion in the country. This shows that if social amenities such as workshop, training centre, etcetera, are not in place, it can dwindle the economic growth of any state or nation as unskilled manpower would take the control of the economy.

The study concluded that VEE is a factor in the economic growth of a nation. Vocational and entrepreneurship also play eminent roles/functions in creating an avenue for economic growth for nations. The study as well concluded that VEE is a twin that may be difficult to separate from economic growth. The study however recommended that VEE should be given the priorities it deserves as it is an important factor for economic growth. Also, public expenditure on VEE must be increased far above its current level in order to improve the human capital in the Ogun State as well as Nigeria.

\section{References}

Alade, I. A. (2011). Effect of socio-economic status, academic ability and motivation on students' academic performance in Basic Technology. Journal of Education, Health and Technology Research, 1 (1), 29-36. 
Emeraton, U. G. (2008). Re-thinking Higher education management for poverty reduction among the youth in Africa. A paper presented at the Third Regional Conference of Higher Education for Youth Empowerment, Opportunities, Capabilities and Second Chance. Organized by Higher Education Research and Policy Network (NERPNET) at IITA, Ibadan, Oyo State, August $18-21$.

Kazmi, S.W. (2007). Vocational Education and Skills Development: A Case of Pakistan, SAARC Journal of Human Resource Development. 105-117.

Mustapha, RB and Greeman, J. P. (2002). The Role of Vocational Education in Economic Development in Malaysia: Educators and Employers' Perspective, Journal of Industrial Teacher Education.

Nilsson, A. (2010). Vocational education and training: an engine for economic growth and a vehicle for social inclusion? International Journal of Training and Development, 14 (4), 251-272.

Oduwaiye, R. O. (2005). Entrepreneurship Education in Nigerian Universities: implementation and way forward,

Oguejiofor, C. S., Ezeabasili, A. C. C. (2014). Imperatives of Vocational Education and Sustainable Development in Nigeria. African Research Review 8 (1), 42-52.

Otuaga, O. U. (2012). The Economic Impacts of Vocational Training in Tertiary Institutions in Nigeria. Journal of Educational and Social Research $2(8), 43-48$.

Uduma, E. C. (2004). An introduction to entrepreneurship in vocational agricultural education, Ogoja: Soyar Printers.

Wennekers S., Van Wennekers, A., Thurik, R., Reynolds, P. (2005). Nascent Entrepreneurship and the Level of Economic Development, Small Business Economics. (24), 293-309. 